\title{
PENGARUH MODEL DISCOVERY LEARNING BERBANTUAN MEDIA GAMBAR BERSERI TERHADAP KETERAMPILAN MENULIS TEKS EKSPLANASI SISWA KELAS VIII SMP NEGERI 25 PADANG
}

\author{
Oleh: \\ Margian Mulya Fitri ${ }^{1}$, Syahrul R. ${ }^{2}$, Afnita ${ }^{3}$ \\ Program Studi Pendidikan Bahasa dan Sastra Indonesia \\ Jurusan Bahasa dan Sastra Indonesia dan Daerah \\ FBSUniversitas Negeri Padang \\ Email: margianmulyaf09@gmail.com
}

\begin{abstract}
The purpose of the research are (1) to describe exsplanatory text writing skills of VIII grade students SMP Negeri 25 Padang before applying discovery learning model whitin serial piscture media, (2) to describe exsplanatory text writing skills of VIII grade students SMP Negeri 25 Padang after applying discovery learning model whitin serial piscture media, and (3) to analize effect of discovery learning model whitin serial piscture media to exsplanatory text writing skills of VIII grade students SMP Negeri 25 Padang. Based on the data analize the application of discovery learning model whitin serial piscture media affects the exsplanatory text writing skills of VIII grade students SMP Negeri 25 Padang.
\end{abstract}

Kata kunci: pengaruh, discovery learning, media gambar berseri, menulis teks

\section{A. Pendahuluan} eksplanasi

Keterampilan menulis teks eksplanasi merupakan salah satu pembelajaran yang dituntut dalam kurikulum 2013 pada mata pelajaran bahasa Indonesia khususnya di tingkat SMP. Pembelajaran keterampilan menulis teks eksplanasi di tingkat SMP diajarkan pada kelas VIII semester dua.Oleh sebab itu, diajarkan kepada siswa bentuk keterampilan menulis teks eksplanasi, tetapi hasilnya belum maksimal.Salah satu faktor yang menyebabkan belum maksimalnya keterampilan menulis teks eksplanasi adalah model pembelajaran.

Model pembelajaran sangat berpengaruh terhadap hasil belajar siswa. Guru hendaknya bisa memilih model pembelajaran yang bervariasi, salah satu contohnya model discovery learning. Berdasarkan beberapa penelitian yang telah dilakukan, model discovery learning dapat meningkatkan hasil belajar siswa.Hal itu dibuktikan dari penelitian yang telah dilakukan di beberapa negara seperti Amerika, Turki, Mesir, dan Indonesia (Joolingen, 2007; Balim, 2009; Mahmoud, 2014; Arifani, 2016).Beberapa penelitian tersebut telah menguji model discovery learning yang hasilnya berdampak positif kepada siswa maupun guru yang menerapkan model tersebut.

Menurut Putrayasa, Syahruddin, dan Margunayasa (2014), berdasarkan hasil penelitian yang telah dilakukan menyatakan bahwa model discovery learning membuat siswa lebih aktif, kreatif, dan efektif dari yang konvensional. Hal ini ditunjukkan dengan uji t dimana nilai t hitung

${ }^{1}$ Mahasiswa penulis skripsi Prodi Pendidikan Bahasa dan Sastra Indonesia wisuda periode Maret 2018

2Pembimbing I, dosen Fakultas Bahasa dan Seni Universitas Negeri Padang

3Pembimbing II, dosen Fakultas Bahasa dan Seni Universitas Negeri Padang 
lebih tinggi dari t tabel $(1,64>1,24)$. Hal tersebut sejalan dengan penelitian yang dilakukan oleh Rosarina, Sudin, dan Sujana (2016), menyatakan bahwa model discovery learning meningkatkan hasil belajar siswa.Keberhasilaninidapatdibuktikan dari berbagaidatapelaksanaan tindakandarisiklusI hinggasiklusIII.

Menurut Priyatni (2014:82), teks eksplanasi berisi penjelasan tentang prosesyang berhubungaan dengan fenomena-fenomena alam, sosial ,ilmu pengetahuan, budaya.Teks eksplanasi berasal dari pertanyaan penulis terkait "mengapa" dan "bagaimana" suatu fenomena terjadi. Teks eksplanasi bertujuan untuk menjelaskan proses pembentukan atau kegiatan yang terkait dengan fenomena-fenomena alam, sosial, ilmu pengetahuan,atau budaya.

Berdasarkan wawancara dengan guru bahasa Indonesia kelas VIII SMP Negeri 25 Padang, Dina Sri Ramayani, S.Pd., pada hari Jumat, 12Januari 2018 dapat disimpulkan bahwa siswa kurang menguasai pembelajaran keterampilan menulis teks eksplanasi. Hal ini dibuktikan dengan nilai ulangan harian siswa kelas VIII tentang keterampilan menulis teks eksplanasi banyak yang tidak mencapai KKM (Kriteria Ketuntasan Minimal) yaitu 70.Siswa kesulitan menulis teks eksplanasi disebabkan oleh sulitnnya mengembangkan ide dalam menulis, kurangnya pengalaman dan wawasan siswa dalam menulis, khususnya menulis teks eksplanasi, siswa mengalami kesulitan dalam menentukan stuktur dan ciri kebahasaan teks eksplanasi dalam tulisannya.

Sehubungan dengan permasalahan yang dihadapi dalam menulis teks eksplanasi, guru mata pelajaran bahasa Indonesia harus terampil menulis dan terampil menggunakan model yang cocok dalam kegiatan pembelajaran menulis. Pemilihan model pembelajaran yang tepat akan mempermudah siswa dalam mengembangkan pikiran ketika menulis, karena model pembelajaran berfungsi sebagai sarana penyampaian pesan dari guru kepada siswa, dengan kata lain siswa belajar akan lebih efektif, produktif, dan bermakna jika hal-hal yang dibaca dan dilihat memberikesan mudah untuk mengembangkan ide, mudah untuk dipahami, dan mudah pula untuk diingat.

Joolingen (2007)menyatakan bahwa discovery learning dipandang sebagai cara belajar yang menjanjikan karena beberapa alasan, yang utama adalah keterlibatan aktif pelajar dengan domain akan menghasilkan basis pengetahuan terstruktur yang lebih baik dalam pembelajaran dibandingkan dengan cara belajar yang lebih tradisional, pengetahuan dikatakan hanya ditransfer ke pelajar. Selanjutnya, Balim (2009) menyatakan bahwa discovery learning sesuai dengan pendekatan konstruktivis yang mempengaruhi siswa agar belajar lebih efektif dengan membangun pengetahuan mereka sendiri.Hal ini sejalan dengan pendapat Mahmoud (2014) menyatakan kekurangan metode pengajaran yang digunakan dalam pengajaran peraturan gramatikal yang menyebabkan turunnya tingkat prestasi.Kemudian, Arifani (2016) menyatakan bahwa pelaksanaan discovery learning meningkatkan kemampuan pelajar dalam menghasilkan topik penyelidikan, mengembangkan draf cadangan penyelidikan dan menulis proposal penyelidikan yang komprehensif.

Pembelajaran menulisteks eksplanasi siswa kelas VIIL SMP Negeri 25 Padang masih banyak mengalami permasalahan, sehingga diperlukan solusi untuk memecahkannya. Dalam penelitian ini, solusi yang dilakukan untuk memecahkan masalah tersebut adalah pemilihan model pembelajaran yang dapat menarik perhatian siswa. Model pembelajaran yang cocok digunakan dengan permasalahan penelitian ini adalah dengan menerapkan model discovery learning. Penerapan model discovery learning ini dibantu dengan sebuah media, yaitu media gambar berseri.

Melalui gambar siswa dapat menerjemahkan ide-ideabstrak dalambentuk lebih realistis.Salah satu gambaryangmenarikdigunakan dalam proses pembelajaran adalah gambar seri. Gambarseri merupakan rangkaian gambar yangmemilikihubunganatau keterkaitan kejadian antara gambar satu dengan gambar yanglainnya.Gambar-gambar tersebutmenceritakan sebuahrangkaian kejadianatau suatu peristiwadariawal kejadiansampaiakhir kejadian.Gambarini mampu merangsangdayapikirsiswa dalammencarisuatu idepokokdalam sebuahwacana sertadapat memecahkan masalahdidalamnya (dalamPutra, 2014:4). 
Pengaruh Model Discovery Learning Berbantuan Media Gambar Berseri terhadap Keterampilan Menulis Teks Eksplanasi Siswa Kelas VIII SMP Negeri 25 Padang-Margian Mulya Fitri, Syahrul R., Afnita

Model discovery learning berbantuan media gambar berseri membuat siswa lebih tertarik dan termotivasi untuk menulis teks eksplanasi. Selain itu, dengan memberikan gambar secara langsung pada siswa akanmembuat rasa ingin tahu siswa muncul. Siswa akan berusaha mengeluarkan ide dan pikirannya serta termotivasi untuk menulis. Berdasarkan hal tersebut, penulis berharap modeldiscovery learning berbantuan media gambar berserimampu menciptakan suasana yang menyenangkan sehingga memotivasi siswa dalam menulis teks eksplanasi.

Tujuan penelitian ini untuk mendeskripsikan hal-hal sebagai berikut.Pertama, mendeskripsikan keterampilan menulis teks eksplanasi siswa kelas VIII SMP Negeri 25 Padang sebelum menggunakan model discoverylearning berbantuan media gambar berseri.Kedua,mendeskripsikan keterampilan menulis teks eksplanasi siswa kelas VIII SMP Negeri 25 Padang sesudah menggunakan model discovery learning berbantuan media gambar berseri.Ketiga, menganalisis pengaruh model discovery learning berbantuan media gambar berseri terhadap keterampilan menulis teks eksplanasi siswa kelas VIII SMP Negeri 25 Padang.

\section{B. Metode Penelitian}

Jenis penelitian ini adalah penelitian kuantitatif.Penelitian ini disebut penelitian kuantitatif karena data penelitian yang diolah berupa angka-angka.Hal ini sejalan dengan pendapat Arikunto (2010:27) bahwa penelitian kuantitatif banyak dituntut menggunakan angka, mulai dari pengumpulan data, penafsiran terhadap data, serta penampilan dari hasilnya.Data penelitian yang diolah berupa angka-angka yang diperoleh dari skor hasil tes keterampilan menulis teks eksplanasi siswa kelas VIII SMP Negeri 25 Padang.

Metode yang digunakan dalam penelitian ini adalah metode eksperimen.Penelitian ini dikatakan dengan metode eksperimen karena bertujuan untuk mengontrol atau mengendalikan setiap gejala yang muncul dalam kondisi tertentu sehingga diketahui hubungan sebab-akibat dari gejala yang terjadi.Jenis eksperimen ini adalah eksperimen semu (quasy-experimental research). Menurut Suryabrata (2011:92), tujuan penelitian eksperimen semu adalah untuk memperoleh informasi yang merupakan perkiraan bagi informasi yang dapat diperoleh dengan eksperimen yang sebenarnya dalam keadaan yang tidak memungkinkan untuk mengontrol atau memanipulasi paling sedikit satu variabel yang relevan, mengontrol variabel lain yang relevan, dan mengobservasi efek atau pengaruh terhadap satu atau lebih variabel terikat.

Rancangan penelitian yang digunakan dalam penelitian ini adalah the one group pretesposttest design.Rancangan penelitian ini merupakan rancangan yang/menggunakan satu kelompok subjek. Pernyataan ini sesuai dengan pendapat Suryabrata (2012:101) yang mengungkapkan bahwa dalam rancangan penelitian the one group pretes-posttest design digunakan satu kelompok subjek. Pertama-tama dilakukan pengukuran, lalu dikenakan perlakuan jangka waktu tertentu, kemudian dilakukan pengukuran untuk kedua kalinya.

Menurut Ibnu (2003:60), populasi adalah semua objek atau subjek yang menjadi sasaran penelitian. Sejalan dengan pendapat Ibnu, Sugiyono (2010:117) mengatakan populasi adalah wilayah generalisasi yang terdiri atas objek/subjek yang mempunyai kualitas dan karakteristik tertentu yang ditetapkan oleh peneliti untuk dipelajari dan kemudian ditarik kesimpulannya.Arifin (2012:214) juga mengatakan populasi adalah keseluruhan objek yang diteliti, baik berupa orang, benda, kejadian, nilai maupun hal-hal yang terjadi. Jadi, populasi tidak hanya orang, tetapi juga objek dan benda-benda yang lain. Berdasarkan pendapat para ahli tersebut, populasi dalam penelitian ini adalah siswa kelas VIII SMP Negeri 25 Padang yang terdaftar pada tahun $2017 / 2018$ yang berjumlah 255 orang.

Penarikan sampel dilakukan dengan teknik purposive sampling. Arikunto (2014:183) menyatakan bahwa pengambilan sampel secara purposive sampling dilakukan dengan cara mengambil subjek bukan didasarkan atas strata, random, atau daerah tetapi didasarkan atas tujuan dan syarat tertentu yang harus dipenuhi, yaitu didasarkan pada ciri pokok populasi, subjek yang diambil paling banyak mengandung ciri populasi, dan dilakukan studi pendahuluan. 
Sampel dalam penelitian ini diambil berdasarkan rata-rata dan standar deviasi kelas pada pelajaran Bahasa Indonesia yaitu kelas VIII.4.

Variabel penelitian ini, yaitu keterampilan menulis teks eksplanasi sebelum menggunakan model discovery learning berbantuan media gambar berseri siswa kelas VIII SMP Negeri 25 Padang dan keterampilan menulis teks eksplanasi sesudah menggunakan model discovery learning berbantuan media gambar berseri siswa kelas VIII SMP Negeri 25 Padang. Data penelitian ini adalah skor hasil tes keterampilan menulis teks eksplanasi siswa kelas VIII SMP Negeri 25 Padang sebelum menggunakan model discovery learning berbantuan media gambar berseri dan skor hasil tes keterampilan menulis teks eksplanasi siswa kelas VIII SMP Negeri 25 Padang sesudah menggunakan model discovery learning berbantuan media gambar berseri.

Instrumen yang digunakan dalam penelitian ini adalah tes unjuk kerja, yaitu tes keterampilan menulis teks eksplanasi. Sebelum instrumen diujicobakan, langkah awal yang dilakukan adalah memvalidasi oleh dosen pembimbing yang mengerti dalam bidang evaluasi pembelajaran serta guru mata pelajaran Bahasa Indonesia kelas VIII SMP Negeri 25 Padang, yaitu Dina Sri Ramayani, S.Pd. selain mendiskusikan instrumen dengan ahlinya, validitas isi instrumen juga dilakukan dengan menyelaraskan instrumen dengan indikator yang digunakan.

\section{Pembahasan}

Pada/bagian ini dibahas mengenai hasil keterampilan menulis teks eksplanasi siswa kelas VIII SMP Negeri 25 Padang sebelum dan sesudah menggunakan model discovery learningberbantuan media gambar berseri. Pertama, keterampilan menulis teks eksplanasi sebelum menggunakan model discovery learningberbantuan media gambar berseri.Kedua, keterampilan menulis teks eksplanasi sesudah menggunakan model discovery learningberbantuan media gambar berseri.Ketiga, pengaruh model discovery learningberbantuan media gambar berseri terhadap keterampilan menulis teks eksplanasi siswa kelas VIII SMP Negeri 25 Padang.

\section{Keterampilan Menulis Teks Eksplanasi Siswa Kelas VIII SMP Negeri 25 Padang Sebelum Menggunakan Model DiscoveryLearning Berbantuan Media Gambar Berseri}

Berdasarkan analisis data diperoleh rata-rata hitung tes keterampilan menulis teks eksplanasi siswa kelas VIII SMP Negeri 25 Padang sebelum menggunakan model discovery learningberbantuan media gambar berseri (pretest) sebesar 59,67. Dari rata-rata hitung tersebut dapat disimpulkan bahwa pretest keterampilan menulis teks eksplanasi berkualifikasiCukup (C).Selain menggunakan rata-rata hitung (M) sebagai tolak ukur, maka untuk menentukan pretest keterampilan menulis teks eksplanasi dapat menggunakan KKM.KKM yang ditetapkan untuk mata pelajaran Bahasa Indonesia di SMP Negeri 25 Padang adalah 70.Oleh karena itu, pretest keterampilan menulis teks eksplanasi lebih rendah dari KKM yang ditetapkan oleh sekolah.

Pretest keterampilan menulis teks eksplanasi dapat dilakukan dengan analisis per indikator. Adapun indikator yang dinilai, sebagai berikut. Pertama, isi teks eksplanasi (1). Ratarata hitung pretest keterampilan menulis teks eksplanasiuntuk indikator 1 adalah 63,28. Hal itu disebabkan masih banyak siswa kurang sesuai dengan topik yang dibahas dalam teks eksplanasi yang mereka tulis. Pengetahuan siswa mengenai isi teks eksplanasi disebabkan teks eksplanasi merupakan teks yang baru dipelajari siswa pada jenjang SMP.

Pengetahuan siswa yang terbatas menjadi alasan dari topik yang dibahas kurang sesuai. Sealin itu, siswa juga kurang bisa dalam mengungkapkan gagasan ke dalam bentuk tulisan. Pada indikator 1, masih banyak siswa yang menulis teks eksplanasi yang kurang sesuai dengan topik yang dibahas.

Kedua,struktur teks eksplanasi (2). Rata-rata hitung pretest keterampilan menulis teks eksplanasi untuk indikator 2 adalah 52,73. Siswa lebih banyak menuliskan mengenai identifikasi fenomena dan rangkaian kejadian pada teks eksplanasi yang ditulisnya.Terdapat tiga bagian 
Pengaruh Model Discovery Learning Berbantuan Media Gambar Berseri terhadap Keterampilan Menulis Teks Eksplanasi Siswa Kelas VIII SMP Negeri 25 Padang-Margian Mulya Fitri, Syahrul R., Afnita

struktur teks eksplanasi, yaitu (a) identifikasi fenomena, (b) rangkaian kejadian, dan (c) ulasan. Identifikasi fenomena yaitu mengidentifikasi sesuatu yang akan diterangkan.Rangkaian kejadian merupakan bagian perincian ata kejadian yang relevan dengan identifikasi fenomena.Ulasan yaitu berupa komentar atau penilaian tentang konsekuensi atas kejadian yang dipaparkan sebelumnya.

Penulisan struktur teks eksplanasi juga masih memuat urutan struktur dan pengemabangan yang kurang logis.Siswa juga masih tampak bingung dalam menyusun urutan dari struktur teks eksplanasi sesuai dengan topik yang dibahas.Hal tersebut disebabkan karena masih banyak siswa yang tidak memperhatikan urutan yang benar dari struktur teks eksplanasi.Dalam indikator 2 tersebut banyak teks eksplanasi yang ditulis siswa tidak terstruktur sehingga teks eksplanasi yang ditulis siswa kurang terperinci.

Ketiga, ciri kebahasaan teks eksplanasi (3). Rata-rata hitung pretest keterampilan menulis teks eksplanasi untuk indikator 3 adalah 62,50. Kebanyakan dari siswa hanya menuliskan satu atau dua dari empat ciri kebahasaan teks eksplanasi.Hal ini tidak sejalan dengan pendapat Kemendikbud (2014) mengemukakan teks eksplanasi memiliki ciri kebahasaan yang relatif berbeda dengan teks lain.Terdapat empat ciri kebahasaan yang terdapat di dalam teks eksplanasi, yaitu (a) konjungsi kausalitas, (b) konjungsi kronologis, (c) benda, dan (d) istilah.

Hal tersebut disebabkan karena banyak dari siswa yang tidak mengetahui pentingnya ciri kebahasaan teks eksplanasi. Ciri kebahasaan teks eksplanasi berfungsi untuk membedakannya dengan teks lain, hal itu karena teks eksplanasi memiliki ciri kebahasaan yang relatif berbeda dengan teks lain. Penyebab lainnya adalah siswa kurang menguasai dan kurang memperhatikan ciri kebahasaan ketika menulis teks eksplanasi.Dalam indikator 3, ciri kebahasaan yang terdapat dalam teks eksplanasi yang ditulis siswa masih kurang.

Keempat, ejaan bahasa Indonesia pada teks eksplanasi (4). Rata-rata hitung pretest keterampilan menulis teks eksplanasi untuk indikator 4 adalah 60,16. Kebanyakan dari siswa memiliki kesalahan dalam penulisan teks eksplanasi.Hal terserbut tidak sesuai dengan Peraturan MenteriPendidikan Dan Kebudayaan RepublikIndonesia Nomor 50 Tahun2015 Pedoman Umum Ejaan Bahasa Indonesia, terdapat peraturan pemakaian huruf, penulisan kata, dan penggunaan tanda baca.

Hal tersebut disebabkan karena banyak dari siswa yang tidak mengetahui/peraturan ejaan penulisan yang baik dan benar dalam bahasa Indonesia. Selain itu, penggunaan ejaan bahasa Indonesia dalam pembelajaran masih jarang dibahas sehingga siswa masih membuat kesalahan yang sama dalam setiap penulisan. Ejaan bahasa Indonesia sangat penting dalam setiap penulisan, termasuk menulis teks eksplanasi.

\section{Keterampilan Menulis Teks Eksplanasi Siswa Kelas VIII SMP Negeri 25 Padang Sesudah Menggunakan Model Discovery learningBerbantuan Media Gambar Berseri}

Berdasarkan analisis data diperoleh rata-rata hitungketerampilan menulis teks eksplanasi siswa kelas VIII SMP Negeri 25 Padang sesudah menggunakan model discovery learningberbantuan media gambar berseri (postest) sebesar 72,27. Dari rata-rata hitung tersebut dapat disimpulkan bahwa postest keterampilan menulis teks eksplanasi berkualifikasi Lebih dari Cukup (LdC). Selain menggunakan rata-rata hitung (M) sebagai tolak ukur, maka untuk menentukan postest keterampilan menulis teks eksplanasi juga dapat menggunakan KKM. KKM yang ditetapkan untuk mata pelajaran Bahasa Indonesia di SMP Negeri 25 Padang adalah 70. Oleh karena itu, postest keterampilan menulis teks eksplanasi lebih tinggi dari KKM yang ditetapkan oleh sekolah.

Postest keterampilan menulis teks eksplanasi dapat dilakukan dengan analisis per indikator.Adapun indikator yang dinilai yaitu sebagai berikut.Pertama, isi teks eksplanasi (1). Rata-rata hitung postest keterampilan menulis teks eksplanasi untuk indikator 1 adalah 75,78. Dibandingkan dengan hasil pretest keterampilan menulis teks eksplanasi, hasil postest keterampilan menulis teks eksplanasi lebih tinggi dari hasil pretest keterampilan menulis teks 
eksplanasi. Hal itu disebabkan dalam pembelajaran menulis teks eksplanasi, siswa sebelumnya diberi latihan menulis teks eksplanasi dengan model discovery learning bantuan media gambar berseri.

Isi teks eksplanasi yang ditulis siswa sudah relevan dengan topik yang dibahas. Selain itu, penjelasan yang dijelaskan tentang bagaimana peristiwa itu terjadi sudah cukup logis dan terperinci.Pada indikator 1 , teks eksplanasi siswa sudah cukup sesuai dengan topik yang dibahas dan cukup terperinci.

Kedua, struktur teks eksplanasi (2). Rata-rata hitung postest keterampilan menulis teks eksplanasi untuk indikator 2 adalah 61,72. Dibandingkan dengan hasil pretest keterampilan menulis teks eksplanasi, hasil postest keterampilan menulis teks eksplanasi lebih tinggi dari hasil pretest keterampilan menulis teks eksplanasi. Jika dilihat dari postest keterampilan menulis teks eksplanasi terlihat siswa sudah mampu menulis teks eksplanasi dengan memperhatikan tiga bagian struktur secara urut dan logis. Hal itu disebabkan dalam pembelajaran menulis teks eksplanasi menggunakan model discovery learning berbantuan media gambar berseri siswa diajarkan bahwa struktur teks eksplanasi dibagi menjadi tiga bagian, yaitu identifikasi fenomena, rangkaian kejadian, dan ulasan. Dengan demikian, pada saat posttest, siswa sudah mulai menulis teks sesuai dengan struktur teks eksplanasi.

Struktur teks eksplanasi pada tulisan siswa sudah urut dan logis. Siswa juga sudah paham dalam menyusun urutan dari struktur teks eksplanasi sesuai dengan topik yang dibahas.Selain itu, siswa juga sudah paham dalam memperhatikan urutan yang benar dari struktur teks eksplanasi.Dalam indikator 2 tersebut banyak teks eksplanasi yang ditulis siswa sudah terstruktur secara urut dan logis.

Ketiga, ciri kebahasaan teks eksplanasi (3). Rata-rata hitung postest keterampilan menulis teks eksplanasi untuk indikator 3 adalah 76,17. Dibandingkan dengan hasil pretest keterampilan menulis teks eksplanasi, hasil postest keterampilan menulis teks eksplanasi lebih tinggi dari hasil pretest keterampilan menulis teks eksplanasi. Kebanyakan dari siswa sudah mampu menggunakan tiga ciri kebahasaan teks eksplanasi.Hal ini sependapat dengan Kemendikbud (2014) mengemukakan teks eksplanasi memiliki ciri kebahasaan yang relatif berbeda dengan teks lain.Terdapat empat ciri kebahasaan yang terdapat di dalam teks eksplanasi, yaitu (a) konjungsi kausalitas, (b) konjungsi kronologis, (c) benda, dan (d) istilah.

Jika dilihat dari teks eksplanasi yang ditulis siswa sesudah menggunakan model discovery learning berbantuan media gambar berseri, terlihat bahwa siswa sudah terampil memaparkan ciri kebahasaan dengan baik, yaitu memuat lebih dari tiga ciri kebahasaan teks eksplanasi. Pada saat posttest, sudah banyak siswa yang mulai mencantumkan ciri kebahasaan dibandingkan pada saat pretest.

Keempat, ejaan bahasa Indonesia pada teks eksplanasi (4). Rata-rata hitung pretest keterampilan menulis teks eksplanasi untuk indikator 4 adalah 75,39. Kesalahan dalam penulisan teks eksplanasi sudah mulai berkurang. Meskipun demikian, kesalahan berupa kesalahan pemakaian huruf, penulisan kata, dan penggunaan tanda baca masih terjadi di beberapa tulisan siswa.

Ketika perlakuan model discovery learning berbantuan media gambar berseriperaturan ejaan penulisan yang baik dan benar dalam bahasa Indonesia juga dijelaskan pada siswa. Hal ini karena melihat hasil tes siswa sebelum menggunakanmodel discovery learning berbantuan media gambar berseri indikator 4 masih memiliki hasil yang rendah Ejaan bahasa Indonesia sangat penting dalam setiap penulisan, termasuk menulis teks eksplanasi.

\section{Pengaruh Penggunaan ModelDiscovery learningBerbantuan Media Gambar Berseri terhadap Keterampilan Menulis Teks Eksplanasi Siswa Kelas VIII SMP Negeri 25 Padang}

Model discovery learningberbantuan media gambar berseri baik untuk diterapkan dalam pembelajaran menulis teks eksplanasi. Hal itu terlihat dari hasil tes keterampilan menulis teks eksplanasi siswa kelas VIII SMP Negeri 25 Padang sesudah menggunakan model discovery 
Pengaruh Model Discovery Learning Berbantuan Media Gambar Berseri terhadap Keterampilan Menulis Teks Eksplanasi Siswa Kelas VIII SMP Negeri 25 Padang-Margian Mulya Fitri, Syahrul R., Afnita

learningberbantuan media gambar berseri lebih tinggi dibandingkan dengan hasil tes keterampilan menulis teks eksplanasi siswa kelas VIII SMP Negeri 25 Padang sebelum menggunakan model discovery learningberbantuan media gambar berseri. Siswa terlihat lebih antusias dalam proses pembelajaran dengan menggunakan model discovery learning berbantuan media gambar berseri. Hal tersebut sejalan dengan pendapat Roestiyah (2008:20) ada tujuh keunggulan model discovery sebagai berikut.Pertama, teknik ini mampu membantu siswa untuk mengembangkan, memperbanyak kesiapan, serta penguasaan keterampilan dalam proses kognitif siswa. Kedua, siswa memperoleh pengetahuan yang bersifat sangat pribadi sehingga dapat lama tertinggal dalam jiwa tersebut.Ketiga, dapat membangkitkan kegairahan belajar para siswa.

Keempat, teknik ini mampu memberikan kesempatan kepada siswa untuk berkembang dan maju sesuai dengan kemampuannya masing-masing.Kelima,mampu mengarahkan cara siswa belajar, sehingga lebih memiliki motivasi yang kuat untuk belajar lebih giat. Keenam, membantu siswa untuk memperkuat dan menambah kepercayaan pada diri sendiri dengan proses penemuan sendiri. Ketujuh, strategi itu berpusat pada siswa bukan pada guru. Guru hanya sebagai teman belajar dan membantu apabila diperlukan.

Berdasarkan uraian tersebut, disimpulkan bahwa guru berperan penting dalam merencanakan, melaksanakan, mengevaluasi, dan memberikan variasi model pembelajaran kepada siswa agar siswa tidak cepat bosan saat belajar, khususnya menulis teks eksplanasi. Salah satu upaya tersebut berupa penggunaan model discovery learning berbantuan media gambar berseri dalam pembelajaran keterampilan menulis teks eksplanasi.Selanjutnya, ditinjau dari hasil menulis teks eksplanasi siswa, keterampilan menulis teks eksplanasi siswa sebelum menggunakan model discovery learning berbantuan media gambar berserilebih rendah dibandingkan dengan hasil menulis teks eksplanasi siswa sesudah menggunakan model discovery learning berbantuan media gambar berseri. Hal itu terbukti dari hasil penelitian yang menunjukkan bahwa keterampilan menulis teks eksplanasi siswa kelas VIII SMP Negeri 25 Padang sebelum menggunakan model discovery learning berbantuan media gambar berseriberada pada kualifikasi Cukup dengan rata-rata 59,67. Sebaliknya, keterampilan menulis teks eksplanasi siswa kelas VIII SMP Negeri 25 Padang sesudah menggunakan model discovery learning berbantuan media gambar berseriberada pada kualifikasi Lebih dari Cukup dengan rata-rata $72,27$.

Demikian juga dengan hasil uji hipotesis diperoleh $\mathrm{T}_{\text {hitung }} 6,24$, sedangkan $\mathrm{T}_{\text {tabel }} 1,70$. Jadi, dapat disimpulkan bahwa model discovery learning berbantuan media gambar berseri berpengaruh secara signifikan dengan taraf $95 \%$ karena $\mathrm{T}_{\text {hitung }}>\mathrm{T}_{\text {tabel }}(6,24>1,70)$. Perbedaan rata-rata keterampilan menulis teks eksplanasi siswa sebelum menggunakan model discovery learning berbantuan media gambar berseridan sesudah menggunakan model discovery learning berbantuan media gambar berseridianggap sebagai pengaruh yang ditimbulkan oleh penggunaan model discovery learning berbantuan media gambar berseritersebut. Dengan demikian, penggunaan model discovery learning berbantuan media gambar berseriberpengaruh terhadap keterampilan menulis teks eksplanasi siswa kelas VIII SMP Negeri 25 Padang

\section{Simpulan dan Saran}

Keterampilan menulis teks eksplanasi siswa kelas VIII SMP Negeri 25 Padang sebelum menggunakan model discovery learning berbantuan media gambar berseri.Pada indikator 1 , beberapa dari siswa yang menulis teks eksplanasi yang kurang sesuai dengan topik yang dibahas.Pada indikator 2, teks eksplanasi yang ditulis siswa tidak terstruktur sehingga teks eksplanasi yang ditulis siswa kurang terperinci.Pada indikator 3, kebanyakan dari siswa hanya menuliskan satu atau dua dari empat ciri kebahasaan teks eksplanas ciri kebahasaan yang terdapat dalam teks eksplanasi yang ditulis siswa masih kurang.Pada indikator 4,masih banyak dari siswa memiliki kesalahan dalam penulisan teks eksplanasi.

Keterampilan menulis teks eksplanasi siswa kelas VIII SMP Negeri 25 Padang sesudah menggunakan model discovery learning berbantuan media gambar berseri.Pada indikator 1,teks 
eksplanasi siswa sudah cukup sesuai dengan topik yang dibahas dan cukup terperinci.Pada indikator 2, banyak teks eksplanasi yang ditulis siswa sudah terstruktur secara urut dan logis.Pada indikator 3, Kebanyakan dari siswa sudah mampu menggunakan tiga ciri kebahasaan teks eksplanasi.Pada indikator 4,masih banyak dari siswa memiliki kesalahan dalam penulisan teks eksplanasiKesalahan dalam penulisan teks eksplanasi sudah mulai berkurang.

Berdasarkan uji-t disimpulkan bahwa terdapat pengaruh yang signifikan dalam penggunaan model discovery learning berbantuan media gambar berseri terhadap keterampilan menulis teks eksplanasisiswa kelas VIII SMP Negeri 25 Padang karena $t_{\text {hitung }}>t_{\text {tabel }}(6,24>1,70)$. Jadi, disimpulkan bahwa pembelajaran keterampilan menulis teks eksplanasi siswa kelas VIII SMP Negeri 25 Padang dengan menggunakan model discovery learning berbantuan media gambar berseri cocok digunakan guru untuk pembelajaran keterampilan menulis teks eksplanasi.

Berdasarkan simpulan yang diperoleh dari hasil penelitian di atas, maka diajukan saransaran sebagai berikut.

Pertama, disarankan kepada guru mata pelajaran Bahasa Indonesia di SMP Negeri 25 Padang agar menerapkan penggunaan model discoveryleraning berbantuan media gambar berseri dalam pembelajaran keterampilan menulis teks eksplanasi.

Kedua, disarankan kepada siswa kelas VIII SMP Negeri 25 Padang untuk lebih banyak berlatih menulis baik di sekolah maupun di luar sekolah, agar keterampilan dalam menulis teks eksplanasi dapat dikembangkan dengan baik dan menjadi terampil.

Ketiga, untuk peneliti, diharapkan untuk dapat mengembangkan lebih lanjut dengan wawasan mengenai penerapan pembelajaran menulis inovatif dan mengaplikasikan teori yang telah diperoleh.

Keempat, / saran untuk peneliti lain diharapkan agar dapat dijadikan sebagai acuan ataupun perbandingan dalam melakukan penelitian yang berkaitan dengan masalah ini.

Catatan: Artikel ini disusun berdasarkan skripsi Margian Mulya Fitri dengan pembimbing I, Prof. Dr. Syahrul R., M.Pd. dan pembimbing II, Dr. Afnita, M.Pd.

\section{Daftar Rujukan}

Arifani, Y. (2016).The Implementation ofTeam-Based Discovery Learning to ImproveStudents'Ability inWriting Research Proposal. International EducationStudies;.Vol.9 (No.2), pp111-119.

Arifin, Z. (2012). Penelitian Pendidikan: Metode dan Paradigma Baru.Bandung: Rosda.

Arikunto, S. (2010).Prosedur Penelitian: Suatu Pendekatan Praktik. Jakarta: Rineka Cipta.

Balim, G. A. (2009). TheEffects of Discovery Learning onStudents Success andInquiry Learning Skills.Eurasian Journal of Education Research. Issue 35, pp 1-20.

Ibnu, Suhadi, dkk. 2003. Dasar-dasar Metodologi Penelitian. Malang: Universitas Negeri Malang.

Joolingen, $\quad$ W. V.

V. (2007).

CognitiveToolsforDiscoveryLearning.InternationalJournalofArtificialIntelligenceinEducati on.Vol.10, pp 385-39.

Mahmoud,

A.

(2014).

TheEffectofUsingDiscoveryLearningStrategyinTeachingGrammaticalRulestofirst yearGeneralSecondaryStudentonDevelopingTheirAchievementandMetacognitive Skills.InternationalJournalofInnovationandScientificResearch. Vol.5 (No.2),pp.146-153. 
Pengaruh Model Discovery Learning Berbantuan Media Gambar Berseri terhadap Keterampilan Menulis Teks Eksplanasi Siswa Kelas VIII SMP Negeri 25 Padang-Margian Mulya Fitri, Syahrul R., Afnita

Priyatni, E.T. (2014). Desain Pembelajaran Bahasa Indonesia dalam Kurikulum 2013.Jakarta: Bumi Aksara.

Putra, Md., dan Ida B. (2014). PengaruhTeknikCriticalIncidentBerbantuan Media Gambar SeriterhadapKeterampilan Menulis KelasVSDGugus1Abiansemal.Jurnal MimbarPGSDUniversitasPendidikanGanesha.Vol.2 (No.1), pp 1-10.

Putrayasa, I. M., dkk.(2014). PengaruhModel PembelajaranDiscoveryLearningdan Minat BelajarterhadapHasil Belajar IPASiswa.Jurnal Mimbar PGSD Universitas Pendidikan Ganesha. Vol.2 (No:1), pp 1-11.

Rosalina, G., dkk. (2016). Penerapan Model Discovery Learning untukMeningkatkanHasilBelajarSiswaPadaMateriPerubahan WujudBenda. Jurnal Pena Ilmiah. Vol.1 (No.1), pp 371-380.

Roestiyah. (2008). Strategi Belajar Mengajar. Jakarta: Rineka Cipta.

Sugiyono. (2010). Metode Penelitian Kuantitatif, Kualitatif, dan R\&D. Bandung: Alfabeta.

Suryabrata, S. (2011).Metodologi Penelitian. Jakarta: Raja Grafindo Persada.

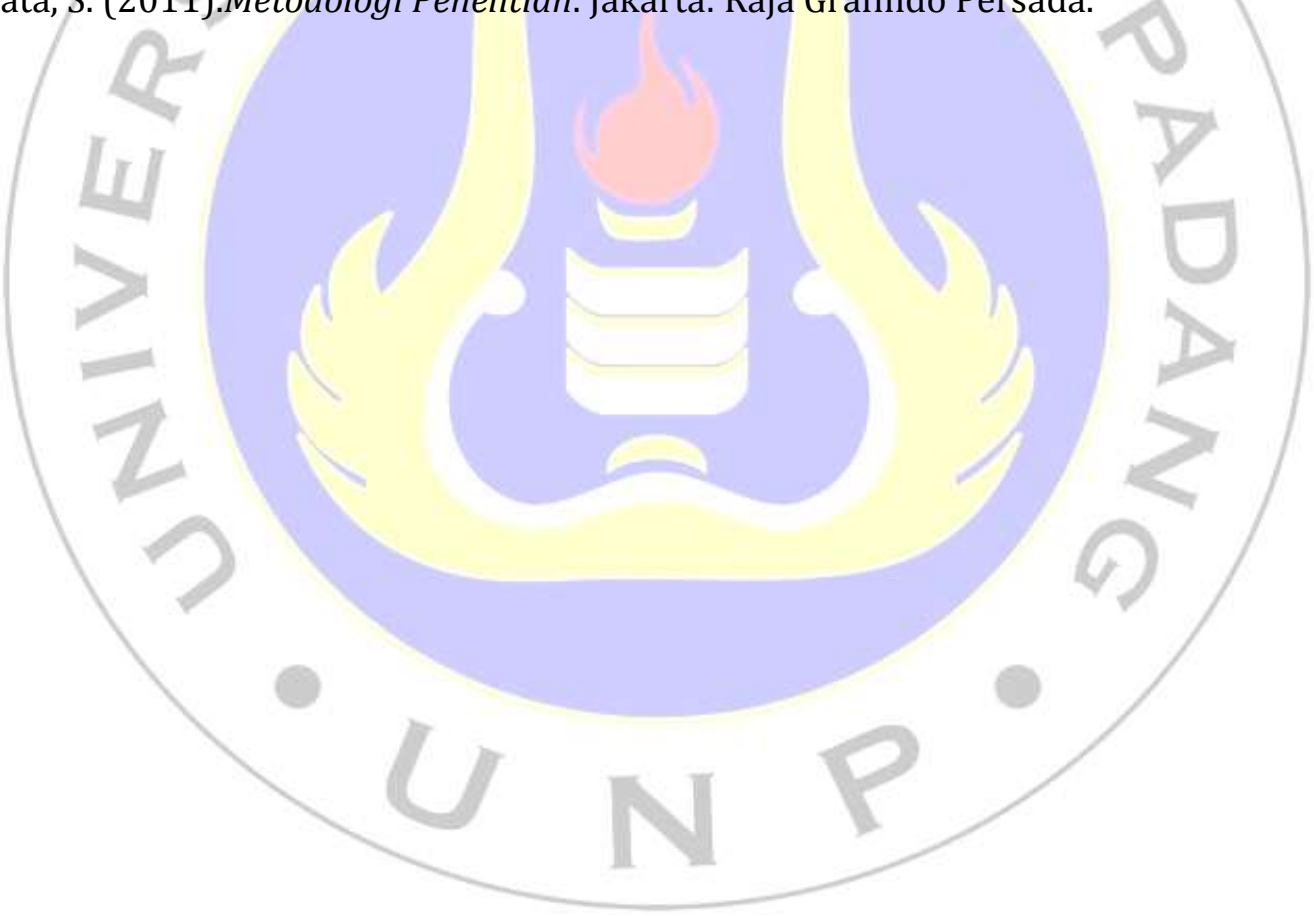

